\title{
THE CHALLENGES OF TOBACCO CONTROL IN ROMANIA
}

POLICY REVIEW

\author{
Patricia R. Loubeau \\ Hagan School of Business, lona College, New Rochelle, New York, USA
}

\begin{abstract}
SUMMARY
This article investigates elements of tobacco control issues in Romania. Using European Union requirements for tobacco control legislation as a backdrop, it examines the key issues of smuggling, taxation, and unemployment in a transitional economy. Romania has made some progress by adding text and pictorial warnings to cigarette packages and offering comprehensive help to quit smoking. Using empirical examples, it is argued that more progress in tobacco control is needed in the area of increased taxation, enforcement of non-smoking bans, and new legislation requiring advertising bans at point of sale, kiosks, and billboards. This article draws wider public attention to the problems that smuggling and taxation present for tobacco control, helps identify other countries confronting similar issues, and stimulates effective interventions.
\end{abstract}

Key words: smoking, tobacco control, Romania, public health, economics

Address for correspondence: P. R. Loubeau, Hagan School of Business, lona College, 715 North Avenue, New Rochelle, NY 10801, USA. E-mail: PLoubeau@iona.edu

Tobacco control legislation has gained prominence at the European Union (EU) level and the rest of the world due to the serious medical effects of smoking. The highest recorded level of smoking was among men and was first recorded in 1948 when surveys started. At that time, $82 \%$ of men were smoking (1). It has been estimated that between 1950 and 2000, 63 million people worldwide have died from tobacco-related diseases (2). Unless urgent action is taken to control the tobacco epidemic, the annual death toll could rise to 8 million by 2030 (3). The concern about smoking has been heightened as evidence mounts about the cost of smoking and the effects of second-hand smoke. According to the 2008 Eurobarometer survey on tobacco summary report issued by the Directorate for Public Health and Risk Assessment of the European Commission, tobacco is the single largest cause of avoidable death, it accounts for over half a million deaths each year in the EU (4).

A "smoke-free Europe" is one of the priorities of the European Commission's public health, environment, employment, and research policy. Progress has been achieved due to legislative efforts and diligent health promotion efforts. In the early nineties, a number of EU health and safety at work directives defined certain restrictions on smoking at work. These were complemented by the Recommendation on Smoking Prevention of 2002 which called on Member States to provide protection from exposure to environmental tobacco in indoor workplaces, enclosed public places, and public transport (5).

National legislation differs widely across Member States. Italy, Malta, Sweden, and parts of the United Kingdom have been cited as having excellent examples of effective measures to protect their citizens from the harmful effects of smoking. Outside of the EU, Norway and Iceland have been lauded as having effective measures for tobacco control. Other countries are less stringent in their legislation to restrict tobacco use. However, there is a clear trend towards smoke-free environments throughout the EU Member States driven by legal requirements and public support at the EU level.

In order to become a part of the EU, a country is legally obligated to comply with and implement certain legal acts. Tobacco control legislation at the EU level consists of legally binding directives and nonbinding resolutions and recommendations regarding tobacco control (6). Romania is a parliamentary democracy and since January 2007, the country has been a member of the European Union. Final acceptance into the EU was based on a number of reforms, including increased law enforcement, environmental measures and the protection of the rights of Roma minority. Therefore, the Romanian regulatory framework has been enacted exogenously in the process of joining the EU. Efforts to reduce tobacco consumption are not straightforward in a country with evolving economy and changes in the political system. The aim of this paper is to connect the economic issues of tobacco control with public health efforts in light of the specific challenges faced by Romania. More broadly, the present research may be seen as a contribution to the literature on tobacco use and control.

In Romania, tobacco has been grown, consumed, and exported for centuries. It is believed that the tobacco culture was brought to Romania by the Turks in the middle of the 16th century. Oriental, semi-oriental and burley tobacco are currently cultivated. During the last hundred years, the habit of cigarette smoking was highly prevalent, socially acceptable and considered a sign of adulthood. In Romania, smoking has a high social acceptance and Romanian youth often see teenagers and adults smoking.

Data available from a 2007 survey found that the smoking prevalence in Romania for those over 25 was $31.0 \%$ (7). For 
comparison in 2007, an estimated 19.8 percent of U.S. adults were current smokers (8). The prevalence of current tobacco smoking is an important predictor of the future burden of tobacco-related diseases. World Health Statistics 2010 reported that the prevalence of smoking any tobacco product among adults aged 15 years or older in 2006 was $49 \%$ for males and $38 \%$ for females, compared to $21.5 \%$ prevalence for males and $16.6 \%$ prevalence for females for the European region in general (9). There is a wide variation in smoking prevalence among EU 27 members. Kaiser and Gommer note that the proportion of those aged 15 years and over who smoke in EU-27 ranges from 16\% in Sweden to 38\% in Greece (10). The most recent comparable data for Romania is for 2009 and indicates that $33.7 \%$ of those aged 15 years and over smoke (11). A study conducted in 2004 in 5 high schools in Romania showed that $11.8 \%$ of students aged $15-17$ years smoked occasionally and $24.5 \%$ reported constant smoking (12). Among health professionals, the percentage of smokers is even higher with a smoking prevalence of $43.2 \%(50.1 \%$ in men and $38.6 \%$ in women) among physicians (13). Table 1 shows that the smoking prevalence in Romania is higher than the EU27 average of $31 \%$ adults smoking.

Antismoking regulations can be classified into two main groups - price or tax-based policies and non-price measures. The non-price policies encompass a whole range of policies including geographic restrictions, tobacco advertising bans, sales limitations, packaging mandates, and health warnings about tobacco consumption. Table 2 and 3 summarize the current legislation on tobacco products currently in force in Romania. Pricing policies to reduce tobacco consumption are essentially tax based policies. The use of tax based policies to reduce consumption in Romania is complex.

The ability of governments to influence tobacco use via higher price depends on the price elasticity of demand. Relatively low price elasticity signifies a small demand and thus the inability of higher taxes to reduce cigarette consumption. One of the most effective means of reducing tobacco consumption is by taxation. With respect to young people, tax increases are the most effective intervention to persuade people to quit or not to start smoking (14). Young people and others with low income tend to be highly sensitive to price increases. Because price is an especially powerful determinant of smoking initiation in youth, it significantly moderates long-term trends in cigarette consumption. In the US, a 10 percent increase in the price of cigarettes can lead to a 4 percent reduction in the demand for cigarettes. This reduction is the result of people smoking fewer cigarettes or quitting altogether (17). Although there is no conclusive data on the impact of pricing

Table 2. Legislation on advertising and distribution of tobacco products

\begin{tabular}{|l|l|l|l|}
\hline Description & Ban & $\begin{array}{c}\text { Partial } \\
\text { restriction }\end{array}$ & Comments \\
\hline
\end{tabular}

\begin{tabular}{|l|c|l|l|}
\hline Direct advertising of tobacco products & \multicolumn{1}{l|}{} \\
\hline National TV & $\mathrm{X}$ & & \\
\hline Cable TV & $\mathrm{X}$ & & \\
\hline National radio & $\mathrm{X}$ & & \\
\hline International TV & $\mathrm{X}$ & & \\
\hline International radio & $\mathrm{X}$ & & \\
\hline Local magazines, newspapers & $\mathrm{X}$ & & \\
\hline Billboards, outdoor walls & $\mathrm{X}$ & & \\
\hline Cinemas & $\mathrm{X}$ & & \\
\hline
\end{tabular}

Indirect advertising of tobacco products

\begin{tabular}{|l|c|l|l|}
\hline $\begin{array}{l}\text { Sponsored events with } \\
\text { tobacco brand }\end{array}$ & $X$ & & \\
\hline Name & & & \\
\hline Promotional discounts & $X$ & & \\
\hline
\end{tabular}

\begin{tabular}{|l|c|l|l|}
\hline \multicolumn{4}{|l|}{ Distribution of tobacco products through various outlets } \\
\hline $\begin{array}{l}\text { Sale of single or unpacked } \\
\text { cigarettes }\end{array}$ & $X$ & & \\
\hline Free samples of cigarettes & $X$ & & $\begin{array}{c}\text { To minors } \\
\text { only }\end{array}$ \\
\hline Duty free shops & $X$ & & \\
\hline
\end{tabular}

\begin{tabular}{|l|c|c|c|}
\hline Smoke-free areas & $X$ & & \\
\hline Health care facilities & & $X$ & \\
\hline Education facilities & & $X$ & \\
\hline Restaurants & & $X$ & \\
\hline Pubs and bars & & $X$ & \\
\hline Indoor workplaces and offices & & & \\
\hline Smoke-free public transit & & & \\
\hline Buses & $X$ & & \\
\hline Taxis & $X$ & & \\
\hline Trains & $X$ & & \\
\hline Domestic air transport & $X$ & & \\
\hline International air transport & $X$ & & \\
\hline
\end{tabular}

Table 1. Smoking prevalence*

\begin{tabular}{|l|c|c|c|c|}
\hline Country & Smoking prevalence & Non-smokers & Ex-smokers & Never smoked \\
\hline EU27 & $31 \%$ & $68 \%$ & $22 \%$ & $46 \%$ \\
\hline Romania & $36 \%$ & $64 \%$ & $17 \%$ & $47 \%$ \\
\hline Bulgaria & $39 \%$ & $62 \%$ & $17 \%$ & $45 \%$ \\
\hline Croatia & $33 \%$ & $67 \%$ & $16 \%$ & $51 \%$ \\
\hline Hungary & $36 \%$ & $64 \%$ & $19 \%$ & $45 \%$ \\
\hline
\end{tabular}

EU27 - European Union Member States.

Figures might not sum to 100 due to rounding.

Source: The Gallup Organisation (15), statistics for Croatia: Goel RK, Budak J. (16).

*Aged 15 and over. 
Table 3. Legislation on health warnings, ingredients/constituents, number of cigarettes per pack and minimum age for buying tobacco

\begin{tabular}{|l|c|c|}
\hline Description & $\begin{array}{c}\text { Required/ } \\
\text { regulated }\end{array}$ & Comments \\
\hline $\begin{array}{l}\text { Minimum age for buying tobacco } \\
\text { products }\end{array}$ & $\mathrm{X}$ & 18 years \\
\hline $\begin{array}{l}\text { Health warnings on tobacco } \\
\text { products }\end{array}$ & $\mathrm{X}$ & \\
\hline $\begin{array}{l}\text { Ensuring that hatch warnings are } \\
\text { rotating }\end{array}$ & $\mathrm{X}$ & \\
\hline Colour, contrast, font size & $\mathrm{X}$ & $\begin{array}{c}\text { Not less than } 30 \% \\
\text { of principal display } \\
\text { area }\end{array}$ \\
\hline Area to cover & $\mathrm{X}$ & \\
\hline Language & $\mathrm{X}$ & \\
\hline Pictorial warnings & $\mathrm{X}$ & \\
\hline Disclosure of ingredient or constituent information \\
\hline To government & $\mathrm{X}$ & \\
\hline On packages &
\end{tabular}

policies on cigarette consumption in Romania, experience from another Eastern European country, Hungary, found that regular tobacco tax increases resulted in decreased cigarette consumption and lower prevalence figures in some population groups (18). Raising taxes on tobacco products is considered a highly effective component of a comprehensive tobacco control strategy.

Cigarette tax is composed of excise tax, ad valorem tax (levied as a percentage of price) and value added tax. According to data from the World Health Organization, the structure of taxation for tobacco products (\%) 2006 for Romania is as follows:

$\begin{array}{ll}\text { Specific excise } & 22.72 \\ \text { Ad valorem excise } & 30.00 \\ \text { VAT } & 19.00 \\ \text { Total tax } & 71.72\end{array}$

In EU countries, total taxes often exceed $75 \%$ when value-added tax (VAT) is included (19). Despite subsequent tax increases, Romanian cigarettes are still less expensive than elsewhere in Europe. Romania increased excise duties in 2009 , yet they continue to lag behind other European areas in its use of a taxing strategy to combat smoking. Governments often hesitate to act decisively when adopting tobacco tax increases for fear that the economy may be harmed through a loss of jobs and income from growing, manufacturing, exporting, and selling tobacco. The direct or indirect pro-smoking lobbying efforts also mitigate efforts to raise cigarette taxes. Further, overall demand for cigarettes may decline so steeply that increased revenue through the higher tax per packet is outweighed by the lower sales volume. This is the case in Romania.

The major tobacco companies in Romania are transnational. State owned companies have all been privatized or closed. Until recently, the most recognized and best selling local brands of cigarettes in Romania were Snagov, Ronson, and Carpati. Snagov disappeared from the market when high tar cigarettes were banned and Carpati stopped production of its un-filtered cigarettes in 2010.

Table 4 shows the price of a pack of cigarettes in Romania for the most popular foreign and local brands (2010).
By comparison, the price of a pack of Marlboro cigarettes in New York City is approximately \$ 10.80 (7.95€) and in France $\$ 9.22(6.78 €)$. The price of a pack of Ronson, the most popular domestic cigarettes in Romania, is 4.7 lei compared to cost per a kilogram of apples 2.39 lei, one loaf of white bread 2.50 lei, 10 eggs 3.69 lei, or a $1 / 2$ liter bottle of local beer (Timisoreana) 5 lei. Price level indices (PLIs) provide a comparison of the countries' price levels with respect to the European Union average: if the price level index is higher than 100 , the country concerned is relatively expensive compared to the EU 27 average and vice versa. The EU average is calculated as the weighted average of the national PLIs, weighted with the expenditures corrected for price level differences. This data indicates that tobacco in Romania is relatively cheap compared to other foods and beverages and to surrounding countries. The PLI for tobacco in Romania is the lowest of all the EU 27 countries. In 2009, the PLI for tobacco in Romania was 47 compared to food (65 PLI) and alcoholic beverages (70 PLI) (20). These numbers confirm that cigarettes are relatively affordable, particularly given the availability of smuggled cigarettes which can be bought even more cheaply.

Corruption and organized crime are linked to cigarette smuggling and are perceived by the public to be widespread in Romania. Organized crime, particularly the type which relates to trafficking of smuggled cigarettes has turned into one of the most important mechanism for unlawful redistribution of national wealth. The smuggling of goods is an important source of income for various groups ranging from political leaders and government officials to people living in border areas. In fact, Romanian police have recently arrested 59 customs officials and border police on charges of taking bribes and involvement in cigarette smuggling. Cigarettes represent perhaps the most popular item for smuggling due to their small size, high price, very large consumption, and high import tax rates. The illicit trade volume of cigarettes sold in Romania increased significantly over the course of 2010 due to an increase in the value added tax to $24 \%$ and wage cuts in the public sector. The effectiveness of tax policies is undermined to sone extent since there are smuggled or counterfeit tobacco products on the market. Smuggled cigarettes are cheaper because taxes and duties are not paid. Tobacco companies assert that increased taxation does not necessarily lead to decreased consumption and increased revenues but to increased smuggling. Additionally, smuggling allows international brands to become affordable to low income consumers and to image conscious young people in developing countries. Recent experience in Romania suggests that tax hikes while leading to a decrease in sales of cigarettes has also led to an increase in black market cigarettes. In Romania, cigarettes are widely available on the black market and producers estimate cigarette contraband will account for almost $30 \%$ of the total market in 2010. Most contraband cigarettes sold in Romania

Table 4. Prices per pack of cigarettes* in Romania for the most popular foreign and local brands in 2010

\begin{tabular}{|l|l|}
\hline Foreign brands price $(€)$ & Local brand price $(€)$ \\
\hline Marlboro 5.7 Lei $(1.34 €)$ & Ronson 4.7 Lei $(1.10 €)$ \\
\hline Pall Mall 5.3 Lei $(1.24 €)$ & \\
\hline Camel 5.7 Lei $(1.34 €)$ & \\
\hline
\end{tabular}

*20 cigarettes per pack. Prices include taxes. 
come from the Republic of Moldova (31.5\%), Ukraine (24\%) and Serbia (21.7\%). Overall, the three countries account for $77 \%$ of the total contraband market (21).

Smuggling in Romania is a complex and multi-factorial issue. Goods that are smuggled are most often those that tend to undergo transformation or like tobacco are consumed. This makes the tracking of smuggled goods more difficult. Cigarettes are high import tax items which make them especially appealing for smugglers and consumers alike. Tobacco companies have little incentive to reduce smuggling as lower priced cigarettes contribute to consumption. The common scheme for smuggling locally produced cigarettes usually involves "export" to a neighbouring country, followed by illegal transport back into the country of origin. Smuggling into Romania can take a variety of forms. Cigarettes have been found hidden among food transported in refrigerated trucks, in metal pipes, in lorries carrying wheat, in wheel rims, and by foot across the borders. Individuals who smuggle by foot across the border between Romania and Ukraine are paid 35 to 50 Euros for each crossing. Smuggling in Romania is further facilitated by its 245 kilometer long coastline of the Black Sea which is difficult to patrol. Due to high import taxes and duty rates, smuggling cigarettes can be a profitable activity. Smugglers arbitrage the differences between lower- and-higher countries. For example, there are huge differences between the price of cigarettes in Ukraine and the European Union. In addition to smuggled cigarettes, the incidence of counterfeit cigarettes continues to diversify and grow in Romania. A recent prosecution in the UK noted that Romania was a transit site for counterfeit cigarettes destined to the United Kingdom from Moldova and Ukraine. These cigarettes generally contain low grade tobacco and excessive levels of nicotine.

Statistics of cigarette smuggling are difficult to locate as the topic does not easily lend itself to being a topic of academic scrutiny. The volume of cigarette smuggling in Romania can in part be measured by the amount of cigarettes seized by customs officials. In the first quarter of March 2010, the authorities confiscated 42 million cigarettes which were double the amount seized during the same period in 2008 (22). One study by a local company estimated that smuggled cigarettes accounted for $24.4 \%$ of the Romanian cigarette market in 2010 (23). There are no officially published estimates for the proportion of cigarettes smuggled.

To combat illicit trade, legislation needs to include measures such as requirements for package markings or creation of a system for conclusively tracking and monitoring products through the entire distribution chain. A specific intra-country task force and more stringent border control may be needed to address this problem. Transparent prosecution of border patrols and customs officials who enable smuggling should be a high priority.

Romania has recently made efforts to increase penalties for smuggling by authorizing the confiscation of vehicles used for smuggling. Romania is not alone in terms of cigarette smuggling issues. The United States also suffer from the same problem. Studies indicate that the States are losing about $\$ 5$ billion annually in tax revenue because of illegal tobacco sales (24). Indeed, a study conducted by Lovenheim estimated that the percentage of consumers who smuggle is between 13 percent and 25 percent nationwide (25). A small convenience sample in Romania seems to indicate that the percentage is higher in Romania.
From 1967 to 1989, Romania was under a totalitarian singleparty state ruled by the communist dictator Nicolae Ceausescu. Since 1990, Romania's political landscape and government have dramatically changed. Today, the country is a parliamentary democracy that includes conservatives, social democrats and even a few leftovers from the left. After the collapse of the communist regime, the country experienced a long and challenging transition period in the 1990's with severe changes in the labour market. Under the previous socialist regime, unemployment was virtually non-existent due to pronounced job security. Romania's painful transition from a centrally planned economy to market-oriented capitalism has produced an economic and social upheaval. This transition has resulted in a high jobless rate, increasing inequality of incomes, and de-industrialization. Although showing signs of recent improvement, unemployment is a burning topic for the current center-right government, irrespective of the considerable differences in data about unemployment from various official sources. The country brings in significant profits from the tobacco industry and in 2009, the tobacco industry was one of the biggest state budget contributors providing over 2 billion Euros from VAT and other taxes as well as providing employment for many (26).

Romania has favourable climatic conditions for the cultivation of basic tobacco blends but compared to its neighbours cultivates a relatively small tobacco crop of low quality. Romania has approximately 10,970 hectares of land devoted to growing tobacco or $1 \%$ of its agricultural land. For comparison, its neighbour to the south, Bulgaria, devotes 42,000 hectares and Moldova to the east devotes 18,608 hectares to growing tobacco (27). Romania does devote a significant economic effort to the manufacturing of cigarettes. The cigarette production in Romania is now completely privatized by multinationals accounting for the vast majority of retail volume. In terms of exports, cigarettes accounted for $1 \%$ of the volume of Romanian exports in 2010 (28). As smoke-free policies motivate some smokers to give up smoking, there may be a loss of profit to the tobacco industry and, consequently, reductions in tobacco-related employment. Among EU members, Romania is the second poorest member with an unemployment rate of $8.4 \%$, dropping exports, and a commitment to the International Monetary Fund to lower its budget deficit to $5.9 \%$ of gross domestic product (29).

The leading international tobacco companies in Romania are British American Tobacco (BAT), followed by Altria Group, Inc. with Japan Tobacco Inc. in third place. In addition to the large international tobacco companies, JBS Trade SRL, Imperial Tobacco Group Plc, Chinese producer Sinoroma Industry and a few other smaller manufacturers tax revenues also contribute to the state budget. Romanian cigarette preferences in recent years have moved from traditionally inexpensive, low-quality cigarettes to more expensive products.

In 2010, the price per pack of cigarettes in Romania almost doubled due to higher taxes and fees imposed by the state. The target goal is to reach the taxation and pricing levels seen in the European Union to discourage illegal trade. Despite all tax increases, the price stayed at one-half to two-thirds of the average price per pack in Europe (30).

Public health officials seem to be at odds with the sector that places emphasis on the contribution of the tobacco industry to tax revenues and values the livelihood of people who make their living from growing, manufacturing or selling tobacco. The major- 
ity of tobacco produced in Romania is produced by small family (lineal) farms concentrated in areas where there are few economic opportunities. The provinces of Walachia, Transylvania, Moldavia, Dobruja, and Banat have soil and climatic conditions that make them most suitable for agriculture (17). In 2000, 10,521 hectares were devoted to tobacco production (31). Family farms receive state support and produce tobacco on a contract basis. Tobacco production employs more labour hours per hectare than other crops such as cereals. These tobacco growers contribute to the national employment rate in a country that is working hard to stimulate its economy. These factors contribute to the push-pull of health versus economy. Still, taxation remains a powerful tool, particularly in the young, to discourage smoking. Additional taxation with revenues earmarked specifically for public health efforts could be imposed.

On 27 January 2006, Romania ratified the WHO Framework Convention on Tobacco Control. Overall, progress on health reforms related to tobacco control in Romania has been mixed. On a positive note, Romania joined the group of countries offering comprehensive help to quit smoking in 2008 (32). The Romanian population has access to toll-free quit lines and nicotine replacement therapy is available in pharmacies without a prescription. One of the core principles of tobacco control policies is to eliminate tobacco smoke to create $100 \%$ smoke free places. In most countries the creation of smoke free environments has proven to be one of the most effective and popular tobacco control interventions. One hundred percent smoke free legislation not only reduces the hazardous health effects of exposure to tobacco smoke but it "denormalizes" smoking habits, resulting in many people quitting (33). While smoking is banned in educational facilities, hospitals, and public transit, smoking in restaurants is still widely prevalent. According to Joossens and Raw, 1\% of tobacco and excise duties were to be used to finance national programmes on tobacco alcohol and drugs from 2007 to 2010 (34). Reliable data from the Romanian government on how this $1 \%$ was actually spent is not readily available.

The issue of tobacco control in Romania is not a simple one and requires a multi-pronged approach. Romania has theoretically accepted and embraced the modern concept of health promotion, which intends to improve the level of public health by tackling health determinants and not just preventing disease. A stronger effort aimed at the entire population is needed to encourage individuals to stop smoking. Ideally, action should include ageand gender-based promotional and educational programmes. Lotrean and Devries concluded that it is advisable to include gender-specific issues in prevention activities targeting Romanian adolescents aged 13-14 years (35). Treatment for smokers who would like to quit should be provided either at reduced cost or free of charge. Training in smoking cessation should be part of the basic curriculum for all health professionals. Even brief and simple advice from health professionals can have a substantial increase in smoking cessation rates. A primary focus of all primary health care providers (nurses, physicians, dentists, and pharmacists) should be efforts and education about smoking cessation. This will be a major challenge given the recent cuts to the Health Ministry's budget, physician strikes, widespread bribery, and crumbling physical plants.

The regulation about smoking in public places and the workplace should become more restrictive and there is the outstanding issue of effective enforcement of existing regulations. Violations of smoking in public areas are a common, customary, and acceptable occurrence. Current regulation should be enforced with very heavy penalties and litigation if necessary. Sanitation inspectors who oversee the implementation of regulation could provide periodic automatic reports to the Minister of Health on what was found and the action taken. Specifically, smoking should be banned in all public places including restaurants, pubs, bars, and public transportation. Further, social marketing efforts should stress non smokers' rights to enjoy a smoke free environment so that individuals will be less tolerant of public exposure to second hand smoke.

Additional efforts are needed with respect to the advertising of tobacco. It is suggested that legislation be enacted to ban advertising at point of sale, kiosks, and on billboards. Regarding promotion, sponsorship, and all forms of indirect advertising, the country would be wise to adopt a total ban on advertising.

In Romania, smoking hazards are outlined in direct health warning labels on cigarette boxes. One side of the box says "Smoking might kill" and the other side says "Smoking harms your health and that of the people around you". Effective measures regulating the packaging and labeling of tobacco products are a key component of a comprehensive tobacco control strategy. Since 2004, it has been possible to accompany such warnings with a picture. Pictorial health warnings on two main sides of tobacco products serve to strengthen the health warning. Evidence from countries where pictorial warnings have already been introduced shows that images have a greater impact than text warnings alone (36). Romania is one of ten European Union countries (Belgium, Latvia, Malta, France, Spain, Denmark, Hungary, the Republic of Ireland, the United Kingdom, and Romania) to include pictures to motivate users to quit and to make tobacco less attractive to young people. The change came into effect in 2008.

It is well known that cigarettes are addictive. The Institute of Medicine, a unit of the National Academy of Sciences, has called for a gradual reduction of the nicotine content of all cigarettes to non-addictive levels (37). While this is a worthy strategy and should be considered as an amendment to Romanian law, this would take years to eliminate addiction. A firmer strategy would be the one that includes raising cigarette taxes to the EU levels, a complete ban of smoking in public places, enforcing the laws against selling tobacco to children, and offering free or inexpensive help to smokers trying to quit. Finally, an economic package that stimulates the economy and reduces the burden of unemployment will do much to close the gap between those who feel the need for tobacco revenues and those who place a higher value on individual human life.

The economic future of Romania is optimistic given the many natural resources of the country and its talented people. Placing a high value on and preserving the health of its citizens is consonant with a forward moving country in the 21 st century. Although this is a challenge for a young democratic government with high unemployment and a state budget that includes a large contribution from tobacco tax revenue, the long term societal cost of smoking vastly outweighs the short term gains.

\section{REFERENCES}

1. Wald N, Nicolaides-Bouman A. UK Smoking Statistics. 2nd ed. Oxford (UK): Oxford University Press; 1991. 
2. Peto R, Lopez AD, Boreham J, Thun M. Mortality from smoking in developed countries: 1950-2000. 2nd ed. [Internet]. Revised June 2006 [cited 2013 Apr 16]. Available from: http://www.ctsu.ox.ac.uk/deathsfromsmoking/download\%20files/Original\%20research/Mortality\%20 from $\% 20$ smoking $\% 20$ in $\% 20$ developed $\% 20$ countries $\% 201950-2000 \% 20$ (2nd\%20ed.).pdf.

3. Media centre [Internet]. Geneva: World Health Organisation; 2009 Dec 9. Only $5.4 \%$ of world's population covered by comprehensive smoke-free laws, news release; [cited 2013 Apr 16]. Available from: http://www.who int/mediacentre/news/releases/2009/smoke_free_laws_20091209/en/.

4. Public health [Internet]. Brussels: European Commission; [updated 2013 Mar 24]. 2008 eurobarometer survey on tobacco. Summary report; [cited 2013 Apr 16]. Available from: http://ec.europa.eu/health/archive/ ph_determinants/life_style/tobacco/documents/eb_253_sum_en.pdf.

5. Green paper: towards a Europe free from tobacco smoke: policy options at EU level. Brussels: European Communities; 2007.

6. Legislating for smoke-free workplaces. Copenhagen: WHO Regional Office for Europe; 2006;

7. Bogdanovica I, Godfrey F, McNeill A, Britton J. Smoking prevalence in the European Union: a comparison of national and transnational prevalence survey methods and results. Tob Control. 2011 Jan;20(1):e4.

8. CDC Newsroom: press release [Internet]. Atlanta: Centers for Disease Control and Prevention; [updated 2008 Nov 13]. Slightly lower adult smoking rates; [cited 2011 Jun 21]. Available from: http://www.cdc.gov/ media/pressrel/2008/r081113.htm.

9. World health statistics 2010. Geneva: World Health Organization; 2010.

10. EUPHIX: European Union Public Health Information System [Internet]. Bilthoven: RIVM; 2009. Kaiser S, Gommer AM. Smoking: Smoking Occurrence - Euphact; [cited 2011 Jun 21]. Available from: http://www. euphix.org/object_document/o4748n27423.html.

11. Public health [Internet]. Brussels: European Commission; 2009. Eurobarometer 72.3 results for Romania; [cited 2011 Jun 11]. Available from: http://ec.europa.eu/public_opinion/archives/ebs/ebs_332 fact_ro_en.pdf.

12. Lotrean LM, Ionut $\mathrm{C}$, de Vries H.Tobacco use among Romanian youth Salud Publica Mex. 2006;48 Suppl 1:S107-12

13. Didilescu C, Munteanu I. The prevalence of smoking in physicians in Romania. Pneumologia. 2000 Apr-Jun;49(2):91-4. (In Romanian.)

14. Green LW. Taxes and the tobacco wars. CMAJ. 1997 Jan 15;156(2):205-6

15. The Gallup Organisation. Survey on tobacco: analytical report [Internet]. Flash Eurobarometer Series 253; 2009 [cited 2013 May 15]. Available from: http://ec.europa.eu/public opinion/flash/fl 253 en.pdf.

16. Goel RK, Budak J. Smoking patterns in Croatia and comparisons with European nations. Cent Eur J Public Health. 2007 Sep;15(3):110-5.

17. Bachman RD, editor. Romania: a country study [Internet]. Washington D.C.: Federal Research Division, Library of Congress; 1991 [cited 2013 Mar 24]. Available from: http://memory.loc.gov/frd/cs/rotoc.html.

18. Szilágyi T. Higher cigarette taxes-healthier people, wealthier state: the Hungarian experience. Cent Eur J Public Health. 2007 Sep;15(3):122-6.

19. European tobacco control report 2007. Copenhagen: WHO Regional Office for Europe; 2007.

20. Eurostat. Statistics in Focus [Internet]. Brussels: European Commission; 2010. Kurkowiak B. Price levels for food, beverages and tobacco across the european market differ significantly: comparative price levels in 37 European countries for 2009; [cited 2013 Mar 24]. Available from: http:// epp.eurostat.ec.europa.eu/cache/ITY_OFFPUB/KS-SF-10-030/EN/KSSF-10-030-EN.PDF

21. Mediafax News Brief [Internet]. Bucharest: Mediafax; 2010. Cigarette smuggling in Romania on upward trend in sept, to $24.4 \%$ of overal market; [cited 2013 Mar 24]. Available from: http://www.mediafax.ro/ english/cigarette-smuggling-in-romania-at-24-4-of-overall-market-insept-survey-7517360.
22. Munteanu M. Romania cracks down on tobacco smugglers. Financial Times [Internet]. 2010 Mar 12 [cited 2013 Mar 24]. Available from: http://www.ft.com/cms/s/0/14820f5c-2dd1-11df-a971-00144feabdc0. html\#axzz1PB0i0gzo.

23. See News - the Corporate Wire [Internet]. Bucharest: See News; 2010 Oct 21. Kotova S. Smuggling to feed one-third of Romania's 2010 cigarette market; [cited 2011 Jun 21]. Available: http://seenews.com/ news/latestnews/cigarettesmugglinginromaniaseenat30_ofoverallmarketin2010-163957/.

24. Fields G. States go to war on cigarette smuggling. Wall Street J [Internet]. 2009 July 20 [cited 2011 Jun 21]. Available from: http://online.wsj.com/ article/SB124804682785163691.html.

25. Lovenheim MF. How far to the border?: the extent and impact of crossborder casual cigarette smuggling. Natl Tax J. 2008 Mar;61(1):7-33

26. Business. Nine O'Clock [Internet]. Bucharest: Nine O'Clock; 2010 May 4. Cracking down cigarette smuggling would get Romania EUR 1 bln. Romania needs that bln! [cited 2013 Mar 24]. Available from http://www. nineoclock.ro/cracking-down-cigarette-smuggling-would-get-romaniaeur-1-bln-romania-needs-that-bln/.

27. Mackay J, Eriksen M. The tobacco atlas. Geneva: World Health Organization, 2002

28. ZF English [Internet]. Bucharest: Ziarul Financiar, 2011 Jan 19. Mihai A. Philip Morris exports $95 \mathrm{~m}$ euros' worth of cigarettes, JTI $35 \%$ of its output; [cited 2013 Mar 24]. Available from: http://www.zf.ro/zf-english/ philip-morris-exports-95m-euros-worth-of-cigarettes-jti-35-of-itsoutput-7904529.

29. Bloomberg Business Week [Internet]. New York: Bloomberg; 2010 Apr 8. Savu I. Romania's unemployment rose to a seven -year high in march; [cited 2013 Mar 24]. Available from: http://www.businessweek.com/.

30. Tobacco. Country report [Internet]. London: Euromonitor International; 2010 Nov. Tobacco in Romania; [cited 2013 Mar 24]. Available from: http://www.euromonitor.com/tobacco-in-romania/report.

31. WHO European country profiles on tobacco control [Internet]. Copenhagen: WHO Regional Office For Europe; 2003. Romania; [cited 2013 Mar 24]. Available at: http://www.who.int/tobacco/media/en/Romania. pdf.

32. WHO report on the global tobacco epidemic, 2009: implementing smokefree environments. Geneva: World Health Organization; 2009.

33. Bostic C, editor. Tobacco Watch: monitoring countries' performance on the global treaty. Washington, DC: Framework Convention Alliance; 2010 .

34. Joossens L, Raw M. Progress in tobacco control in 30 European countries, 2005 to 2007. In: Conference paper of the 4th European Conference Tobacco or Health; 2007 Aug 11; Basel, Switzerland [Internet]. Berne: Swiss Cancer League; 2007 [cited 2013 Mar 24]. Available from: http://www. cancer.dk/NR/rdonlyres/7976C5B7-0608-429D-9E94-B0E93274E22E/0/ Sammenligningafrygeforebyggelsei30europ\%25C3\%25A6iskelande.pdf.

35. Lotrean LM, De Vries H. Identifying gender differences among Romanian non-smoking junior high school students. Cent Eur J Public Health. 2012 Mar;20(1):33-7.

36. Directive 2001/37/EC of the European Parliament and of the Council of 5 June 2001 on the approximation of the laws, regulations and administrative provisions of the Member States concerning the manufacture, presentation and sale of tobacco products. 2001 July 18. Off J Europ Communities. 2001 Jul 18;44(L194);26-34.

37. Bonnie RJ, Stratton K, Wallace RB, editors. Ending the tobacco problem: a blueprint for the nation. Washington, DC: National Academies Press; 2007. 